\section{Towards an optimal sampling effort for paternity analysis in forest trees: what do the raw numbers tell us?}

\section{Cristina Leonarduzzi, Stefano Leonardi, Paolo Menozzi, Andrea Piotti}

The ever-increasing use of paternity analysis to estimate the dispersal capability of forest trees calls for a quantitative evaluation of potential errors due to sampling design. Previous studies on optimal sampling strategies for seed trapping experiments suggested a link between sampling effort and error rate in the reconstruction of the seed dispersal kernel. We considered 92 papers on paternity analysis to quantitatively assess the sampling strategy used to study the characteristics of pollen dispersal patterns (pollen immigration rate, distribution of male reproductive success and estimates of pollen dispersal kernel parameters). For each studied stand we report data on the sampling effort (the total number of sampled seeds, the number of mother trees and the number of seeds per mother tree) and additional information on the studied species and characteristics of the sampling areas. The reviewed papers used a median of 8 mother trees (acting as pollen traps in paternity analysis studies), a median of 29 seeds per mother tree and a median of 240 total sampled seeds. These are values (especially the number of mother trees) lower than usually found in classical seed trapping studies, for which accuracy and precision of seed dispersal estimates had already been assessed. These findings underline the need of evaluating the consequences of realistic sampling efforts on the estimation of parameters describing the pollen dispersal pattern to provide the basis for meaningful guidelines to paternity analysis.

Keywords: Sampling scheme, Pollen-mediated gene flow, Dispersal, Seed trapping, Inverse modeling

\section{Introduction}

Paternity analysis is based on the evaluation of the compatibility between the genotypes of adult male individuals and the male genotypic contribution to seeds, and is the preferred method for estimating pollen-mediated gene flow in natural plant populations. Tracking of pollen movements that led to successful fertilization of ovules provides an estimate of the "realized" gene flow. Paternity analysis requires the sampling of all

$\square$ Department of Environmental Sciences, University of Parma, v.le G.P. Usberti 11/A, I-43124, Parma (Italy)

@, Andrea Piotti (andrea.piotti@gmail.com)

Received: Dec 06, 2011 - Accepted: Feb 01, 2012

Citation: Leonarduzzi C, Leonardi S, Menozzi P, Piotti A, 2012. Towards an optimal sampling effort for paternity analysis in forest trees: what do the raw numbers tell us? iForest 5: 18-25 [online 2012-02-27] URL:

http://www.sisef.it/iforest/ contents/? id=ifor0606-009

Communicated by: Marco Borghetti males (hereafter referred to as "potential pollen donors") within a defined area and a sample of seeds collected from fruiting trees acting as pollen traps (hereafter "mother trees") from the same area. In monoecious species, mother trees are also potential pollen donors. After genotyping all potential pollen donors, mother trees and collected seeds, the assignment of paternity can be carried out with various analytical methods whose pros and cons have recently been reviewed by Jones et al. (2010). The main aim of paternity analysis is to correctly identify the true father of any collected seed (or to detect immigrant pollen when no local pollen donor is compatible with seed genotype). Results from paternity analysis (pollen immigration rate, distribution of male reproductive success and estimates of pollen dispersal kernel parameters) are thought to be affected by the resolution of the marker set used and by genotyping errors (Burczyk et al. 2006, Bacles \& Ennos 2008).

Paternity analysis is a powerful tool for the study of within-population pollen dispersal patterns. The short distance component of the dispersal pattern has strong influence in shaping fine-scale genetic structure, that in turn determines the rate and direction of mi- croevolutionary changes at the population level (Pluess et al. 2009). In isolated and low density populations, paternity analysis allows to trace pollination events at a larger scale (the long distance component of the dispersal pattern). It is well-established that forest tree pollen is able to travel hundreds of kilometres and evidence is accumulating that after such long-distance dispersal events pollen is viable and can successfully fertilize seeds (Williams 2010, Robledo-Arnuncio 2010, Buschbom et al. 2011). The possibility of quantifying effective pollination over long distance has profound consequences on the study of how genes have travelled in past and ongoing tree migrations, and may contribute to a sound forecasting of tree responses to anthropogenic and natural global changes (Savolainen et al. 2007). In addition, risk assessment of pollen escape from GM plantation and predictions on the spread of invasive alien species strongly depend on an accurate estimate of the long distance component of pollen dispersal kernel (Williams 2005).

The impact of sampling scheme on the results from paternity analysis has received relatively little attention. A few studies assessed the effects of location and number of seed traps and number of seeds collected in each trap in classical seed trapping experiments. Data from these studies are usually analyzed following a backward approach (so-called "inverse modeling") aimed at reconstructing the dispersal kernel from the spatial location and the fecundity of potential parents and the spatial pattern of seeds collected from traps (Ribbens et al. 1994). Skarpaas et al. (2005) used a simulation approach to optimize seed trap sampling design around a point source. They showed how traps arranged in transects and sectors provide a better kernel estimation than other sampling schemes. Annuli and grid arrays outcompeted other schemes only when the anisotropy of dispersal was unknown. Pielaat et al. (2006) found that a trade-off between nearby and distant sampling is needed to accurately characterize the tail of the dispersal kernel. It is also well known that a random placement of traps within a rectangular or circular area determines an uneven sampling of distance classes, leading to the over-representation of the intermediated ones (Ghosh 1951).

So far, the most relevant study whose results on sampling effort can be easily extended to the case of paternity analysis is the one by Robledo-Arnuncio \& Garcia (2007). They proposed a maximum-likelihood procedure to estimate the seed dispersal kernel from the exact identification of seed sources, as in the case of parentage assignment based on genetic compatibility. This method (Competing Sources Model - CSM) works out the 
problem of the uneven distribution of mother-trap potential distances by taking into account the spatial arrangement of seed traps relative to source plants. It provides better estimates of seed dispersal kernel parameters compared to standard maximum likelihood fitting used in inverse modeling (Robledo-Arnuncio \& Garcia 2007). Jones \& Muller-Landau (2008) compared different approaches to estimate dispersal kernel parameters and confirmed that CSM is among the most accurate and robust methods. From the results of simulations on different sampling scenarios in Robledo-Arnuncio \& Garcia (2007) some practical recommendations on sampling effort emerged. For example, it was shown that fewer seeds are required to properly estimate the average dispersal dis tance (hereafter " $\delta$ ") with respect to the shape parameter (hereafter " $b$ ") of the exponential power kernel (a widely used and flexible curve to describe seed and pollen dispersal), and that for a fixed total number of seeds increasing the number of traps is more useful than collecting more seeds per trap for reducing estimation uncertainty.

Sampling for paternity analysis differs substantially in the number of traps from the one for inverse modeling. In paternity analysis a large number of mother trees per population is rarely sampled (see for instance Schuster \& Mitton 2000 and Oddou-Muratorio et al 2005 for some exceptions), whereas in inverse modeling 10 to 300 traps are usually placed (Stoyan \& Wagner 2001, Pairon et al. 2006, Jones et al. 2008). However, quantitative assessments or qualitative indications about the spatial arrangement of mother trees and the total number of seeds, mother trees, and seeds per mother tree can seldom be found in the literature on paternity analysis An inadequate or insufficient sampling effort (too few sampled seeds and/or mother trees) can lead to a biased estimation of the withinpopulation pollination pattern. In addition, the lack of standard sampling methods limits the comparison among studies to draw general conclusions.

In the present work we review 92 paternity analysis papers to provide a quantitative as sessment of the sampling strategy upon which the estimate of pollen-mediated gene flow rate, the reconstruction of pollen dispersal kernel and the description of male reproductive success distribution are based. We report data on the sampling effort (the total number of sampled seeds, the number of mother trees and the number of seeds per mother tree) and discuss possible consequences and limitations in the sampling scheme on paternity analysis results.

\section{Materials and Methods}

We searched for published studies using paternity analysis to estimate pollen-mediated gene flow in forest trees. We used 3 dif- ferent databases (Google Scholar ${ }^{\mathrm{TM}}$, ISI Web of Science ${ }^{\mathrm{TM}}$ and Scopus ${ }^{\mathrm{TM}}$ ) for surveying the literature. The key-words used were: paternity analysis, tree*, pollen, genetic* and gene flow. We also tracked references: (i) within the articles found; (ii) from review papers on gene flow in forest trees (Burczyk et al. 2004, Ashley 2010); (iii) from Table 4 in Bittencourt \& Sebbenn (2007); and (iv) from Appendix A-1 in Wang et al. (2010a). Studies based on both mating models (as MLTR - Ritland 2002) and pollen pool heterogeneity (as KINDIST - Robledo-Arnuncio et al. 2007) were excluded since they require only to genotype seeds (and mother trees). Studies based on methods such as MLTR (Ritland 2002) and KINDIST (Robledo-Arnuncio et al. 2007) were excluded since they require only to genotype seeds and mother trees. Moreover, we did not consider a few studies for which we were unable to obtain the full-text. Since the focus of our paper is on the sampling strategy, studies based on previously published data or metanalyses were also excluded in order to avoid duplicates. We included paternity studies carried out in seed orchards and studies investigating gene flow among closely related species (e.g., Quercus spp.).

For each selected paper we recorded:

- information on sampling strategy: the total number of sampled seeds, the number of mother trees and the average number of seeds per mother tree;

- characteristics of the studied population: number of potential pollen donors, number of potential pollen traps (female individuals in the population for dioecious species), area, tree density;

- the studied species, its family and taxonomic group, breeding system and primary pollination vector;

- the method and molecular markers used for paternity assignment.

In monoecious species the number of male individuals is equal to the number of female individuals. Whenever life history traits could not be found in the text, we tried to gather them from other sources (e.g., on-line databases), or in some cases from personal communications with the Authors. When density was not available in the text it was inferred dividing the number of individuals within the study population by the stand area. As a general rule, papers either providing a poor description of the sampling design or lacking many essential data were excluded from our dataset.

In papers with multiple stands (e.g., when a system of several forest fragments is studied), data were collected for every stand where at least one seed was genotyped to estimate the pollen-mediated gene flow characterizing that stand (or a group to which the specific stand belongs as, for instance, in Lander et al. 2010). In studies where the same stand was analyzed in two or more consecutive years, if data on sampling effort were reported for each year and they differed, we considered each year as an independent data point.

As for studies carried out in seed orchards or for species that reproduce vegetatively, the number of ramets was taken as the number of individuals, since ramets (rather than genets) represent spatially distinct pollen sources.

\section{Results and Discussion}

\section{General contents and sources}

We collected data from 92 papers published from 1992 to September 2011. Among them, 14 were also present in Burczyk et al. (2004) and 27 in Ashley (2010). In the latter work, the literature search was only on native plants (cultivated trees and crops were excluded) and microsatellite-based studies, but experiments based on parentage analysis were also taken into account. The author stated that her search was not exhaustive, but "broadly inclusive and representative".

The number of papers published per year increased until 2008, followed by a slight decrease in the following years. The general growing trend seems related to the increasing availability of microsatellite markers and to the development of methods based on maximum likelihood assignment of paternities (Fig. 1). The most used methods (simple exclusion - SE, neighborhood model - NM, and maximum likelihood - ML) have similar sampling requirements. The main difference concerns the spatial distribution of pollen donors to be sampled. As for SE and ML-based studies, all potential pollen donors within the sampling area must be sampled, whereas for NB-based studies sampling is carried out within circular areas of a given radius surrounding $n$ mother trees.

Few studies performed paternity analysis using multiple analytical methods $(n=8,9 \%)$. The use of multiple approaches for the estimation of gene flow rates has been recently proposed to overcome possible drawbacks related to specific methods and/or weaknesses due to low-resolution marker sets (Bacles \& Ennos 2008, Jones et al. 2010). Almost half the papers $(47 \%)$ were published in only 4 journals, with Heredity and Molecular Ecology clearly representing the preferred journals for gene flow studies based on paternity analysis (respectively, $15 \%$ and $14 \%$ ), followed by Forest Ecology and Management and Conservation Genetics (Fig. 2).

\section{Studied species and sampling areas}

The collected papers covered a total of 81 different species. Most studies $(n=75,81 \%)$ were conducted on Angiosperms, whereas only 17 studies focused on Gymnosperms. 


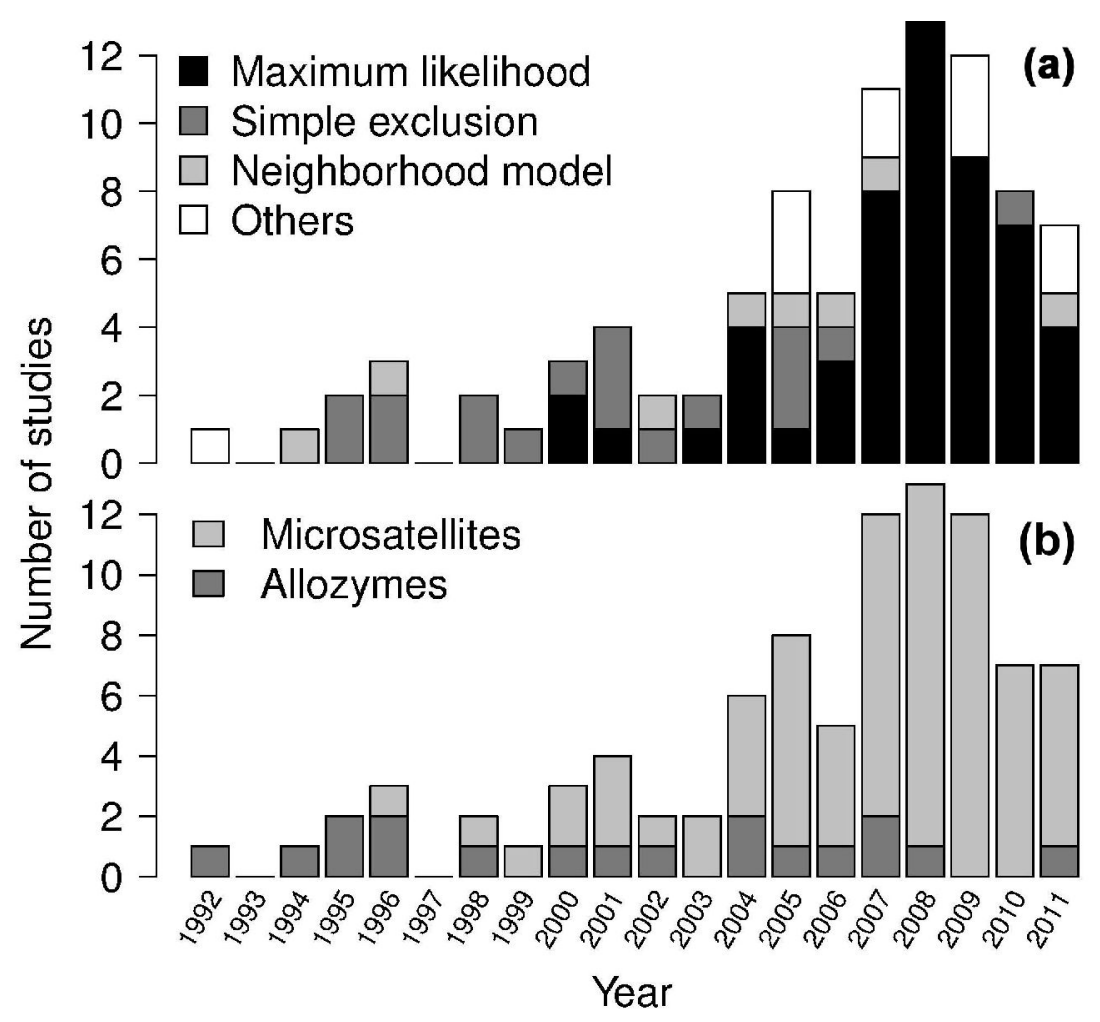

Fig. 1 - Number of published studies per year. Different colors represent: (a) different methods in the analysis of paternity data; and (b) different molecular markers. In papers based on maximum likelihood methods, data analysis was usually performed by the CERVUS (Kalinowski et al. 2007) and FaMoz (Gerber et al. 2003) software. In papers based on the neighbourhood model, data analysis was usually performed according to the methods presented in Burczyk et al. (2002) - implemented in the NM+ program by Chybicki \& Burczyk (2010a) - and Oddou-Muratorio et al. (2005).

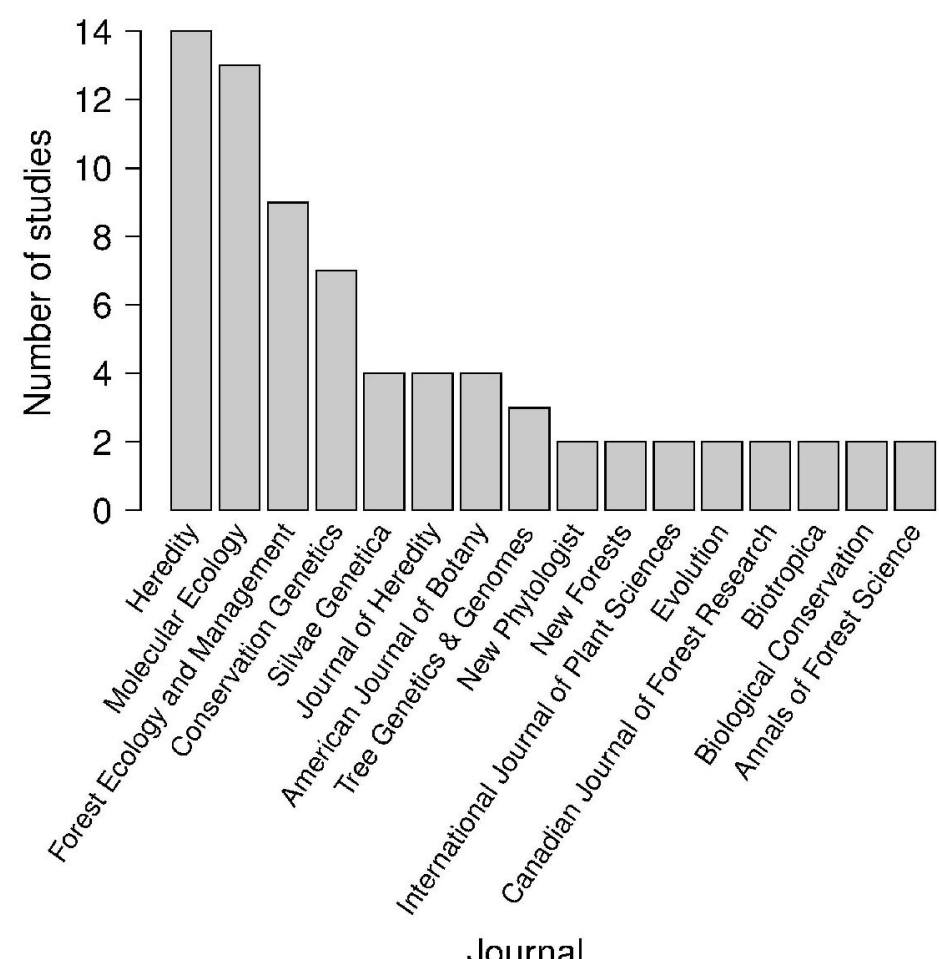

Fagaceae (16) and Pinaceae (12) were the most represented families and, together with Fabaceae and Dipterocarpaceae, represented the studied species in almost half of the collected papers. Overall, species from 30 different families were studied. The large number of gene flow papers on Fagaceae was also reported by Ashley (2010). With regard to the primary pollination vector, there were 46 studies on insect-pollinated species $(50 \%), 38$ on wind-pollinated species $(41 \%)$, while in the remaining 8 articles the studied species relies on mammals, birds, or multiple vectors for pollination.

We obtained 187 data points from the 92 collected papers (see Appendix 1). Fiftyeight papers $(63 \%)$ investigated a single stand, providing a single data point. Papers with more than one data point were fairly frequent $(\mathrm{n}=34,37 \%)$. In general, this is due to the analysis of multiple stands within the same article. Wang et al. (2010b) studied pollen-mediated gene flow in 28 fragments of Pinus tabulaeformis in an urban landscape. According to our criteria, we retained 25 data points, the largest number of data points from a single study in our dataset. Also Lander et al. (2010) sampled a large number of forest fragments to estimate pollen immigration, but only a half of them matched our criteria, providing 13 data points. On the other hand, 11 papers investigated gene flow in the same stand over multiple years (usually, 2 or 3 consecutive years). Irwin et al. (2003) highlighted that single-season studies may not capture temporal variability in pollen exchange, especially in perennial plants where flowering does not occur every year. Therefore, multi-year analyses were advocated for obtaining accurate estimates of pollen-mediated gene flow patterns.

Fig. 2 - Number of studies published per journal. Journals with only 1 published study were excluded.

In general, our knowledge on pollen-mediated gene flow for a species is based on a single study. Only 14 species were analyzed in more than one paper. Quercus robur was investigated in three papers, while Araucaria angustifolia, Cryptomeria japonica, Eucalyptus grandis, Eurycorymbus cavaleriei, Fagus sylvatica, Picea abies, Populus nigra, Prunus avium, Pseudotsuga menziesii, Q. macrocarpa, Q. salicina, Shorea leprosula and Sorbus torminalis were studied twice. The lack of independent estimates, along with the usually low degree of comparability among pollen-mediated gene flow studies, makes generalization on single estimates far-fetched. Studies designed for allowing meaningful comparisons among gene flow rates estimated in different ecological conditions are also rare. The importance of such comparative studies in characterizing the pollen dispersal capability of a species is discussed in Piotti et al. (in press).

The median area of the 118 stands for which we found sufficient information was 
7.42 ha. Small stands $(\leq 1 \mathrm{ha})$ are fairly common $(24 \%)$. Two thirds were smaller than 20 ha, whereas larger stands ( $\geq 100 \mathrm{ha}$ ) are rare $(8 \%)$. This pattern is likely determined by the rapid increase in sampling and genotyping effort with size of the sampled area. Studies on large areas are suitable for the detection of rare long-distance dispersal events, though they are feasible only when species are present at low density. However, Hardy (2009) pointed out that, despite their great importance, the measures of dispersal obtained in such studies might not be representative of species with similar pollination syndrome at higher densities. Comparying two natural Populus trichocarpa stands dramatically different as for density (993 vs. 0.2 males $\mathrm{km}^{-2}$ ) and area (19.6 vs. $31400 \mathrm{ha}$ ), Slavov et al. (2009) found large differences in pollination patterns, although the authors themselves warned about the difficulty of comparing such different areas. Piotti et al. (in press) compared two close Fagus sylvatica stands with regular densities characterized by different management regimes. They found a more skewed pollen dispersal distance distribution in the managed area whose density is about one-third of the unmanaged one (57 vs. 163 trees $\mathrm{ha}^{-1}$ ). Information on the size of sampling areas can also be useful to understand if limits in sampling scale may downwardly bias dispersal range estimates. Nonetheless, heterogeneity of experimental setups and methods used, as well as variation in population densities, pollination syndromes, pollen terminal velocity, stand isolation, etc. should be carefully taken into account in data collection and analysis for future works on this topic. However, methods to estimate dispersal parameters taking advantage of spatially censored data (Jones et al. 2008) or assuming the immigration rate to be a function of dispersal kernel (Goto et al. 2006) are already available but rarely applied. These approaches allow to take into account immigration events of unknown origin in the estimation of the dispersal curve, usually resulting in a substantially higher mean dispersal distance (Piotti et al. 2009, Chybicki \& Burczyk 2010b).

\section{Sampling strategy}

In any of the papers collected for this study, we found neither exhaustive justifications for the sampling strategy adopted, nor references to any guideline for sampling strategy. An exception was the paper by OddouMuratorio et al. (2005), who stated that "the objectives for both years were to sample all possible distances between mother trees, and to maximize the number of mother trees in the middle part of the study site". A paragraph in their discussion focused on the methodological insights for the estimation of the dispersal kernel. Many papers reported a map of the sampling area showing the loca-

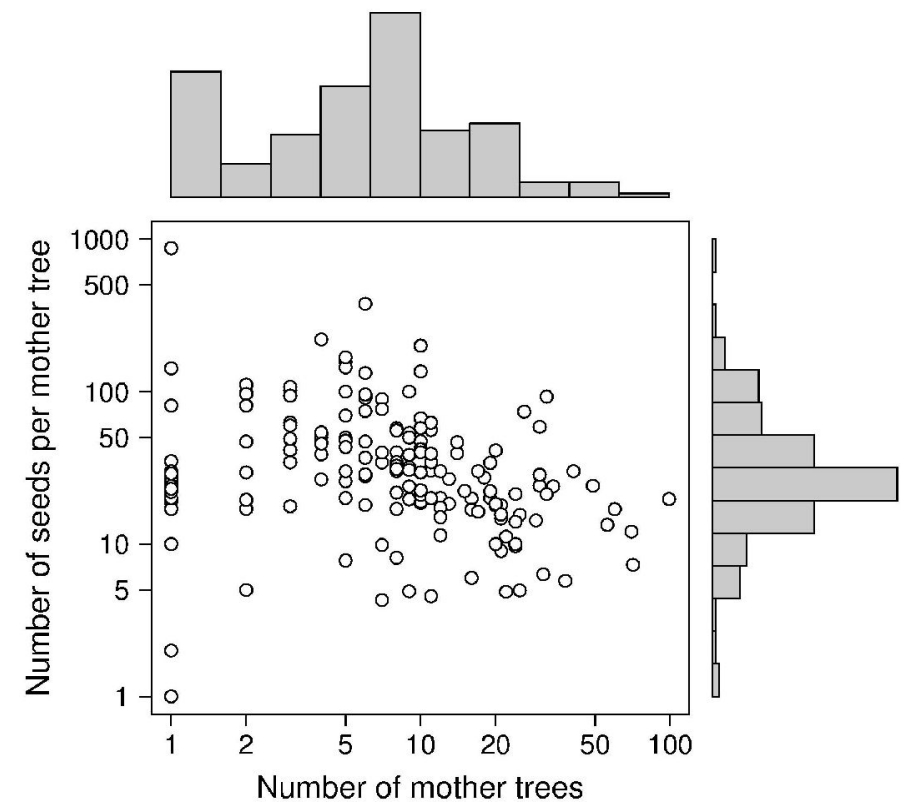

Fig. 3 - Distributions of the number of mother trees ( $\mathrm{x}$ axis) and number of sampled seeds per mother tree (y-axis) in $\log$ scale. White dots represent the 187 data points collected for this study. tion of adult individuals with mother trees indicated by different symbols (e.g., OddouMuratorio et al. 2003, Nakanishi et al. 2004, Curtu et al. 2009). Based on visual inspection of these maps, no clear patterns in the
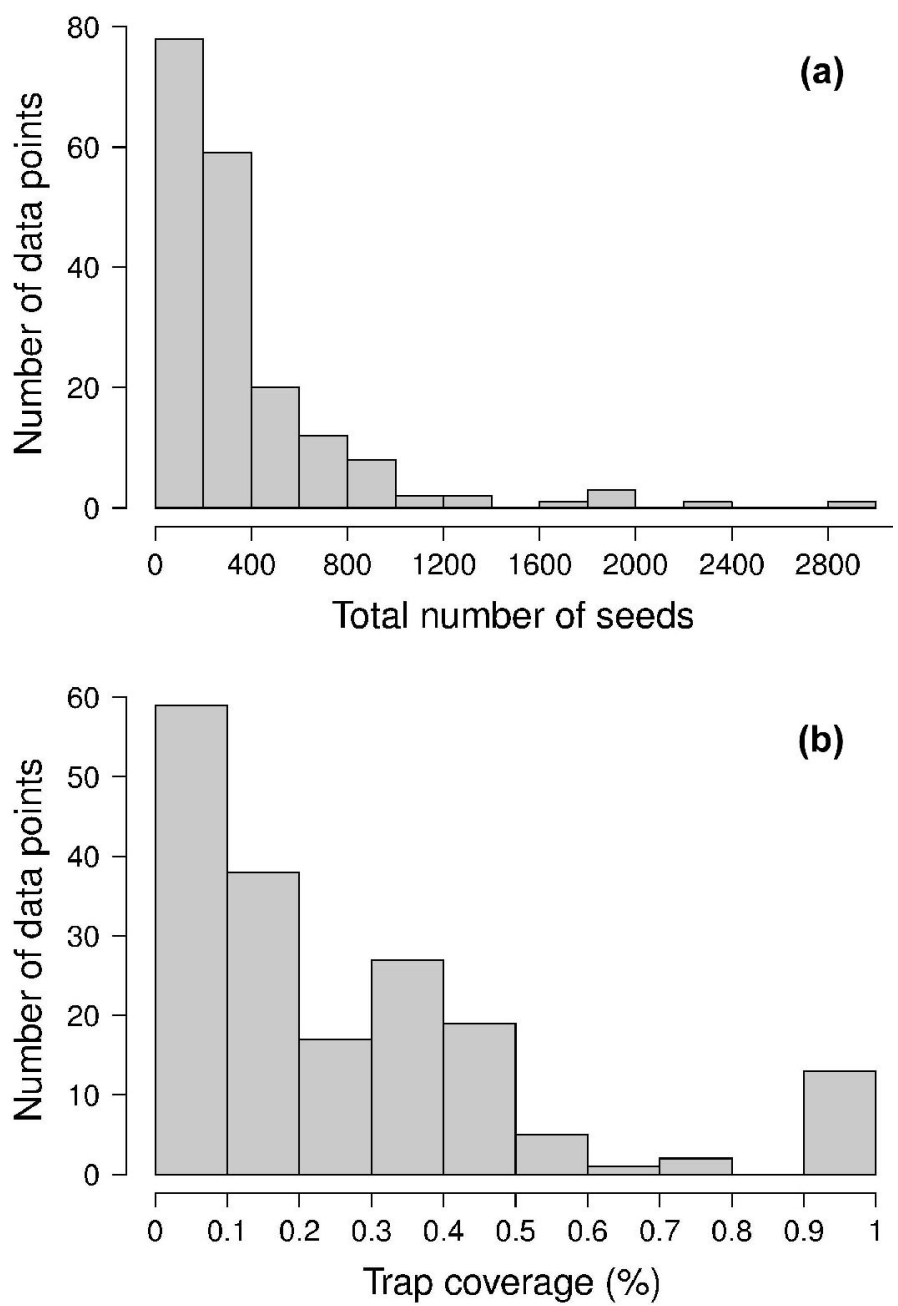

Fig. 4 - Distributions of (a) the total number of seeds, and (b) the percentage of trap coverage characterizing the 187 data points. 
trees in the collected papers. Given this lack of indications and our experience on the difficulties in sampling seeds from forest trees, we feel that such diverse sampling schemes might arise from practical constraints rather than a thorough a priori evaluation. As pointed out in methodological papers on seed dispersal modeling, intuitively designed experiments are likely to lead to incomparable and non-representative results (Willson 1993, Stoyan \& Wagner 2001).

Besides the spatial positioning of mother trees, the other crucial factor in designing a solid sampling scheme for paternity analysis is the sampling effort, represented by the total number of sampled seeds (i.e., number of mother trees $\mathrm{x}$ number of seeds per mother tree). In the collected papers, we found a median number of 8 mother trees (mean $=$ $11.3 \pm 13.6$ SD - Fig. 3), 29 seeds per mother tree $($ mean $=45.6 \pm 74.7 \mathrm{SD}-$ Fig. 3$)$ and 240 total sampled seeds (mean $=356.1 \pm$ 423.1 SD - Fig. 4a). These values are lower than those usually found in classical seed trapping studies. This difference is likely to depend on the need for larger samples to infer dispersal kernel's parameters without genetic data and, on the other hand, on the significant investment of time and resources to collect genetic data (Jones \& Muller-Landau 2008). As a measure of the coverage of potential pollen traps in a stand (trap coverage) the ratio of mother trees over the total number of female trees was calculated. The median value of trap coverage was 0.18 (mean $=0.28 \pm 0.27 \mathrm{SD}-$ Fig. $4 \mathrm{~b}$ ). The above parameter was not correlated with tree density, but it negatively depends on the total number of female trees, indicating that trap coverage is more exhaustive in small populations. The low trap coverage in large stand studies can be related to practical and economic limitations. Nevertheless, a sufficiently high trap coverage is desirable to decrease confidence interval of parameter estimates and increase comparability among results from different experiments.

Our data on the distribution of sampling effort in published paternity analyzes are comparable with the ones from Robledo-Arnuncio \& Garcia (2007), though their work was focused on studying seed dispersal with seed trapping and genetic data. By using a simulation approach, they tested the performance of the CSM by randomly placing 20, 100 and 200 traps in a squared area, and sampling 1 to 50 seeds per trap (total number of sampled seeds: 200-1000). They found that the CSM performs well in the estimation of the $\delta$ parameter even for a relatively small number of seeds (200), whereas $\geq 500$ seeds are needed to obtain an accurate estimate of the $b$ parameter of the dispersal kernel. As the authors noted, the $b$ parameter is more sensitive than the $\delta$ parameter to decreasing number of total seeds and seed traps. The minimum number of traps they simulated was 20 , that is low for classical seed trapping experiments (being therefore adequate for the aims of their paper), but almost double the mean number of mother trees in paternity studies. Among the few indications in the literature about sampling effort in paternity analysis, Oddou-Muratorio et al. (2005) noted that increasing the number of mother trees from 14 to 60 (in the same area in two consecutive years) sensibly reduces the confidence interval of the parameters of the dispersal kernel. On the other hand, the authors pointed out that sampling a high number of seeds per mother tree, that usually limits the number of mother trees, could be more adequate for the estimation of individual selfing rates. This implies that sampling strategy in paternity analysis should be fine-tuned to meet the specific aims of an experiment.

\section{Conclusions}

Although some results on the consequences of different sampling schemes are available for seed trapping studies (with or without genetic assignment of seeds), the case of paternity analysis, usually based on a lower sampling effort, is poorly investigated. Our data collection from the literature on paternity analysis in forest trees showed a potential lack of knowledge about the effects of low numbers of mother trees, seeds per mother tree and total sampled seeds on estimates usually obtained to describe within-population pollination patterns: (i) pollen immigration; (ii) male reproductive success; and (iii) parameters of the pollen dispersal kernel. Only in 29 out of the 187 collected data points $(15 \%)$ the number of mother trees is higher than 20, the lowest number of traps taken into account by Robledo-Arnuncio \& Garcia (2007). This means that for $85 \%$ of our collected data points we have little idea about how accurate and precise the estimates from paternity analysis can be. From Table 2 in Robledo-Arnuncio \& Garcia (2007) we know that the relative root mean square error (RMSE - a measurement of both accuracy and precision of an estimate normalized to the expected value) is $\sim 0.04$ for the $\delta$ parameter and $\sim 0.10$ for the $b$ parameter when 500 seeds were sampled. RMSEs increased to $\sim 0.07$ and $\sim 0.17$, respectively, when the total number of seeds decreased to 200. Errors roughly increase with the inverse of the square root of the total number of seeds sampled, as expected from classical statistical theory. Consequently, when the sampling effort is scarce non negligible errors in estimates are expected, in particular for the $b$ parameter. Leonarduzzi et al. (in preparation), relying on the distribution of sampling effort presented here, explore the consequences of realistic sampling strategies on the reconstruction of different dispersal kernels to provide the basis for meaningful guidelines for paternity analysis.

\section{Aknowledgments}

The authors are grateful to Elia Vajana for help during literature survey and data collection and to Brad Oberle for English revision and suggestions on an early version of the manuscript. We also thank two anonymous reviewers for helpful comments.

\section{References}

Adams WT (1992). Gene dispersal within forest tree populations. New Forests 6: 217-240. - doi: 10.1007/BF00120646

Apsit VJ, Hamrick JL, Nason JD (2001). Breeding population size of a fragmented population of a Costa Rican dry forest tree species. Journal of Heredity 92: 415-420. - doi: 10.1093/jhered/92. 5.415

Ashley MV (2010). Plant parentage, pollination, and dispersal: how DNA microsatellites have altered the landscape. Critical Reviews in Plant Sciences 29: 148-161. - doi: 10.1080/07352689. 2010.481167

Bacles CFE, Burczyk J, Lowe AJ, Ennos RA (2005). Historical and contemporary mating patterns in remnant populations of the forest tree Fraxinus excelsior L. Evolution 59: 979-990. doi: 10.1111/j.0014-3820.2005.tb01037.x

Bacles CFE, Ennos RA (2008). Paternity analysis of pollen-mediated gene flow for Fraxinus excelsior L. in a chronically fragmented landscape. Heredity 101: 368-380. - doi: 10.1038/hdy.2008. 66

Bai WN, Zeng Y-F, Zhang D-Y (2007). Mating patterns and pollen dispersal in a heterodichogamous tree, Junglans mandshurica (Junglandaceae). New Phytologist 176: 699-707. - doi: 10.1111/j.1469-8137.2007.02202.x

Bittencourt JVM, Sebbenn AM (2007). Patterns of pollen and seed dispersal in a small, fragmented population of the wind-pollinated tree Araucaria angustifolia in southern Brazil. Heredity 99: 580-591. - doi: 10.1038/sj.hdy. 6801019

Bittencourt JVM, Sebbenn AM (2008). Pollen movement within a continuous forest of windpollinated Araucaria angustifolia, inferred from paternity and TwoGener analysis. Conservation Genetics 9: 855-868. - doi: 10.1007/s10592-0079411-2

Boshier D, Chase MR, Bawa KS (1995). Population genetics of Cordia alliodora (Boraginaceae), a Neotropical tree. 3. Gene flow, neighborhood, and population substructure. American Journal of Botany 82: 484-490. - doi: 10.2307/ 2445695

Braga AC, Collevatti RG (2011). Temporal variation in pollen dispersal and breeding structure in a bee-pollinated Neotropical tree. Heredity 106: 911-919. - doi: 10.1038/hdy.2010.134

Buiteveld J, Bakker EG, Bovenschen J, de Vries SMG (2001). Paternity analysis in a seed orchard of Quercus robur L. and estimation of the 
amount of background pollination using microsatellite markers. Forest Genetics 8: 331-337. Burczyk J, Adams WT, Shimizu JY (1996). Mating patterns and pollen dispersal in a natural knobcone pine (Pinus attenuata Lemmon.) stand. Heredity 77: 251-260. - doi: 10.1038/hdy. 1996.139

Burczyk J, Adams WT, Moran GF, Griffin AR (2002). Complex patterns of mating revealed in a Eucalyptus regnans seed orchard using allozyme markers and the neighbourhood model. Molecular Ecology 11: 2379-2391. - doi: 10.1046/j 1365-294X.2002.01603.x

Burczyk J (2004). Local pollen dispersal and distant gene flow in Norway spruce (Picea abies Karst.). Forest Ecology and Management 197: 39-48. - doi: 10.1016/j.foreco.2004.05.003

Burczyk J, DiFazio SP, Adams WT (2004). Gene flow in forest trees: how far do genes really travel? Forest Genetics 11: 179-192.

Burczyk J, Adams WT, Birkes DS, Chybicki IJ (2006). Using genetic markers to directly estimate gene flow and reproductive success parameters in plants on the basis of naturally regenerated seedlings. Genetics 173: 363-372. - doi: 10.1534/genetics.105.046805

Buschbom J, Yanbaev Y, Degen B (2011). Efficient long-distance gene flow into an isolated relict oak stand. Journal of Heredity 102: 464-472. - doi: 10.1093/jhered/esr023

Byrne M, Elliott CP, Yates C, Coates DJ (2007). Extensive pollen dispersal in a bird-pollinated shrub, Calothamnus quadrifidus, in a fragmented landscape. Molecular Ecology 16: 1303 1314. - doi: 10.1111/j.1365-294X.2006.03204.X Byrne M, Elliott CP, Yates C, Coates DJ (2008) Maintenance of high pollen dispersal in Eucalyptus wandoo, a dominant tree of the fragmented agricultural region in Western Australia. Conservation Genetics 9: 97-105. - doi: 10.1007/ s10592-007-9311-5

Carneiro FS, Degen B, Kanashiro M, de Lacerda AEB, Sebbenn AM (2009). High levels of pollen dispersal detected through paternity analysis from a continuous Symphonia globulifera population in the Brazilian Amazon. Forest Ecology and Management 258: 1260-1266. - doi 10.1016/j.foreco.2009.06.019

Chaix G, Gerber S, Razafimaharo V, Vigneron P, Verhaegen D, Hamon S (2003). Gene flow estimation with microsatellites in a Malagasy seed orchard of Eucalyptus grandis. Theoretical and Applied Genetics 107: 705-712. - doi: 10.1007/ s00122-003-1294-0

Chase MR, Moller C, Kesseli R, Bawa KS (1996). Distant gene flow in tropical trees. Nature 383 398-399. - doi: 10.1038/383398a0

Chybicki IJ, Burczyk J (2010a). NM+: software implementing parentage-based models for estimating gene dispersal and mating patterns in plants. Molecular Ecology Resources 10: 10711075. - doi: 10.1111/j.1755-0998.2010.02849.x

Chybicki IJ, Burczyk J (2010b). Realized gene flow within mixed stands of Quercus robur L. and $Q$. petraea (Matt.) L. revealed at the stage of naturally established seedlings. Molecular Eco- logy 19: 2137-2151. - doi: 10.1111/j.1365-294X. 2010.04632.x

Cloutier D, Hardy OJ, Caron H, Ciampi AY, Degen B, Kanashiro M, Schoen DJ (2007). Low inbreeding and high pollen dispersal distances in populations of two Amazonian Forest tree species. Biotropica 39: 406-415. - doi: 10.1111/j. 1744-7429.2007.00266.x

Cottrell JE, Vaughan SP, Connolly T, Sing L, Moodley DJ, Russell K (2009). Contemporary pollen flow, characterization of the maternal ecological neighbourhood and mating patterns in wild cherry (Prunus avium L.). Heredity 103: 118-28. - doi: 10.1038/hdy.2009.39

Craft KJ, Ashley MV (2010). Pollen-mediated gene flow in isolated and continuous stands of bur oak, Quercus macrocarpa (Fagaceae). American Journal of Botany 97: 1999-2006. - doi: 10.3732/ajb.0900390

Curtu AL, Gailing O, Finkeldey R (2009). Patterns of contemporary hybridization inferred from paternity analysis in a four-oak-species forest. BMC Evolutionary Biology 9: 284. - doi: 10.1186/1471-2148-9-284

de Lacerda AEB, Kanashiro M, Sebbenn AM (2008). Long-pollen movement and deviation of random mating in a low-density continuous population of a tropical tree Hymenaea courbaril in the Brazilian Amazon. Biotropica 40: 462-470. doi: 10.1111/j.1744-7429.2008.00402.x

de Moraes MLT, Sebbenn AM (2011). Pollen dispersal between isolated trees in the Brazilian savannah: a case study of the neotropical tree $\mathrm{Hy}$ menaea stigonocarpa. Biotropica 43: 192-199. doi: 10.1111/j.1744-7429.2010.00679.x

Dick CW (2001). Genetic rescue of remnant tropical trees by an alien pollinator. Proceedings of the Royal Society of London Series B-Biological Sciences 268: 2391-2396. - doi: 10.1098/rspb. 2001.1781

Dow BD, Ashley MV (1998). High levels of gene flow in Bur oak revealed by paternity analysis using microsatellites. Journal of Heredity 89: 6270. - doi: 10.1093/jhered/89.1.62

Dunphy BK, Hamrick JL (2005). Gene flow among established Puerto Rican populations of the exotic tree species, Albizia lebbeck. Heredity 94: 418-425. - doi: 10.1038/sj.hdy.6800622

Dunphy BK, Hamrick JL (2007). Estimation of gene flow into fragmented populations of Bursera simaruba (Burseraceae) in the dry-forest life zone of Puerto Rico. American Journal of Botany 94: 1786-1794. - doi: 10.3732/ajb.94.11. 1786

Fuchs EJ, Hamrick JL (2011). Mating system and pollen flow between remnant populations of the endangered tropical tree, Guaiacum sanctum (Zygophyllaceae). Conservation Genetics 12: 175-185. - doi: 10.1007/s10592-010-0130-8

Fukue Y, Kado T, Lee SL, Ng KKS, Muhammad N, Tsumura Y (2007). Effects of flowering tree density on the mating system and gene flow in Shorea leprosula (Dipterocarpaceae) in Peninsular Malaysia. Journal of Plant Research 120: 413-420. - doi: 10.1007/s10265-007-0078-Z

Funda T, Chen CC, Liewlaksaneeyanawin C, Ken- awy AM, El-Kassaby YA (2008). Pedigree and mating system analyses in a western larch (Larix occidentalis Nutt.) experimental population. Annals of Forest Science 65 (7): 705-705. - doi: 10.1051/forest:2008055

Gaino APSC, Silva AM, Moraes MA, Alves, PF, Moraes MLT, Freitas MLM, Sebbenn AM (2010). Understanding the effects of isolation on seed and pollen flow, spatial genetic structure and effective population size of the dioecious tropical tree species Myracrodruon urundeuva. Conservation Genetics 11: 1631-1643. - doi: 10.1007/s10592-010-0046-3

García C, Arroyo JM, Godoy JA, Jordano P (2005). Mating patterns, pollen dispersal, and the ecological maternal neighbourhood in a Prunus mahaleb L. population. Molecular Ecology 14: 1821-1830. - doi: 10.1111/j.1365-294X.2005. 02542.x

Geng Q, Lian C, Goto S, Tao J, Kimura M, Islam MS, Hogetsu T (2008). Mating system, pollen and propagule dispersal, and spatial genetic structure in a high-density population of the mangrove tree Kandelia candel. Molecular Ecology 17: 4724-4739. - doi: 10.1111/j.1365-294X. 2008.03948.x

Gerber S, Chabrier P, Kremer A (2003). FAMOZ: a software for parentage analysis using dominant, codominant and uniparentally inherited markers. Molecular Ecology Notes 3: 479-481. doi: 10.1046/j.1471-8286.2003.00439.x

Ghosh P (1951). Random distance within a rectangle and between two rectangles. Bulletin of Calcutta Mathematical Society 43: 17-24

Goto S, Shimatani K, Yoshimaru H, Takahashi Y (2006). Fat-tailed gene flow in the dioecious canopy tree species Fraxinus mandshurica var. japonica revealed by microsatellites. Molecular Ecology 15: 2985-2996. - doi: 10.1111/j.1365294X.2006.02976.x

Gregorius HR, Kownatzki D, Höltken AM (2011). Spatial patterns of mating relations in wild cherry (Prunus avium L.). Perspectives in Plant Ecology, Evolution and Systematics 13: 37-45. doi: 10.1016/j.ppees.2010.11.003

Grosser C, Potts B, Vaillantcourt RE (2010). Microsatellite based paternity analysis in a clonal Eucalyptus nitens seed orchard. Silvae Genetica 59: 57-62.

Hanaoka S, Yuzurihara J, Asuka Y, Tomaru N, Tsumura Y, Kakubari Y, Mukai Y (2007). Pollen-mediated gene flow in a small, fragmented natural population of Fagus crenata. Canadian Journal of Botany 85: 404-413. - doi: 10.1139/ B07-036

Hansen OK, Kjær ED (2006). Paternity analysis with microsatellites in a Danish Abies nordmanniana clonal seed orchard reveals dysfunctions. Canadian Journal of Forest Research 36: 10541058. - doi: 10.1139/x05-299

Hanson TR, Brunsfeld SJ, Bryan F, Waits LP (2008). Pollen dispersal and genetic structure of the tropical tree Dipteryx panamensis in a fragmented Costa Rican landscape. Molecular Eco$\operatorname{logy} 17:$ 2060-2073. - doi: 10.1111/j.1365-294X. 2008.03726.x 
Hardy OJ (2009). How fat is the tail? Heredity 103: 437-438. - doi: 10.1038/hdy.2009.120

Hasegawa Y, Suyama Y, Seiwa K (2009). Pollen donor composition during the early phases of reproduction revealed by DNA genotyping of pollen grains and seeds of Castanea crenata. New Phytologist 182 (4): 994-1002. - doi: 10.1111/j. 1469-8137.2009.02806.x

Hoebee SE, Arnold U, Düggelin C, Gugerli F, Brodbeck S, Rotach P, Holderegger R (2007). Mating patterns and contemporary gene flow by pollen in a large continuous and a small isolated population of the scattered forest tree Sorbus torminalis. Heredity 99: 47-55. - doi: 10.1038/sj. hdy. 6800962

Hufford KM, Hamrick JL, Rathbun SL (2009). Male reproductive success at three early life stages in the tropical tree Platypodium elegans. International Journal of Plant Sciences 170: 724734. - doi: 10.1086/599075

Irwin AJ, Hamrick JL, Godt MJW, Smouse PE (2003). A multiyear estimate of the effective pollen donor pool for Albizia julibrissin. Heredity 90: 187-194. - doi: 10.1038/sj.hdy.6800215

Isagi Y, Kanazashi T, Suzuki W, Tanaka H, Abe $\mathrm{T}$ (2004). Highly variable pollination patterns in Magnolia obovata revealed by microsatellite paternity analysis. International Journal of Plant Sciences 165: 1047-1053. - doi: 10.1086/423883 Jones FA, Chen J, Weng G, Hubbell SP (2011). A genetic evaluation of seed dispersal in the neotropical tree Jacaranda copaia (Bignoniaceae). The American Naturalist 166 (5): 543-555. - doi: 10.1086/491661

Jones FA, Muller-Landau HC (2008). Measuring long-distance seed dispersal in complex natural environments: an evaluation and integration of classical and genetic methods. Journal of Ecology 96: 642-652. - doi: 10.1111/j.1365-2745. 2008.01400.x

Jones ME, Shepherd M, Henry R, Delves A (2008). Pollen flow in Eucalyptus grandis determined by paternity analysis using microsatellite markers. Tree Genetics and Genomes 4: $37-$ 47. - doi: 10.1007/s11295-007-0086-0

Jones AG, Small CM, Paczolt KA, Ratterman NL (2010). A practical guide to methods of parentage analysis. Molecular Ecology Resources 10: 6-30. - doi: 10.1111/j.1755-0998.2009.02778.x

Kalinowski ST, Taper ML, Marshall TC (2007). Revising how the computer program CERVUS accommodates genotyping error increases success in paternity assignment. Molecular Ecology 16: 1099-1006. - doi: 10.1111/j.1365-294X. 2007.03089.x

Kameyama Y, Isagi $\mathrm{Y}$, Naito $\mathrm{K}$, Nakagoshi N (2000). Microsatellite analysis of pollen flow in Rhododendron metternichii var. hondoense. Ecological Research 15: 263-269. - doi: 10.1046/j.1440-1703.2000.00347.x

Kamm U, Rotach P, Gugerli F, Siroky M, Edwards P, Holderegger R (2009). Frequent longdistance gene flow in a rare temperate forest tree (Sorbus domestica) at the landscape scale. Heredity 103: 476-482. - doi: 10.1038/hdy.2009. 70
Kaufman SR, Smouse PE, Alvarez-Buylla ER (1998). Pollen-mediated gene flow and differential male reproductive success in a tropical pioneer tree, Cecropia obtusifolia Bertol. (Moraceae): a paternity analysis. Heredity 81: 164-173. - doi: 10.1046/j.1365-2540.1998.00377.x

Kenta T, Isagi Y, Nakagawa M, Yamashita M, Nakashizuka T (2004). Variation in pollen dispersal between years with different pollination conditions in a tropical emergent tree. Molecular Ecology 13: 3575-3584. - doi: 10.1111/j.1365294X.2004.02345.x

Konuma A, Tsumura Y, Lee CT, Lee SL, Okuda T (2000). Estimation of gene flow in the tropical-rainforest tree Neobalanocarpus heimii (Dipterocarpaceae), inferred from paternity analysis. Molecular Ecology 9: 1843-1852. - doi: 10.1046/ j.1365-294x.2000.01081.x

Lander TA, Boshier DH, Harris SA (2010). Fragmented but not isolated: contribution of single trees, small patches and long-distance pollen flow to genetic connectivity for Gomortega keule, an endangered Chilean tree. Biological Conservation 143: 2583-2590. - doi: 10.1016/j.biocon.2010.06.028

Larsen AS, Kjaer ED (2009). Pollen mediated gene flow in a native population of Malus sylvestris and its implications for contemporary gene conservation management. Conservation Genetics 10: 1637-1646. - doi: 10.1007/s10592008-9713-z

Latouche-Hallé C, Ramboer A, Bandou E, Caron H, Kremer A (2004). Long-distance pollen flow and tolerance to selfing in a neotropical tree species. Molecular Ecology 13: 1055-1064. - doi: 10.1111/j.1365-294X.2004.02127.x

Lee SL, Ng KKS, Saw LG, Lee CT, Muhammad N, Tani N, Tsumura Y, Koskela J (2006). Linking the gaps between conservation research and conservation management of rare dipterocarps: a case study of Shorea lumutensis. Biological Conservation 131: 72-92. - doi: 10.1016/j.biocon.2006.02.005

Leinemann L, Hattemer H (2006). Genetic variation and mating pattern in a stand of yew (Taxus baccata L.). Allgemeine Forst und Jagdzeitung 177: 217-224.

Nakanishi A, Tomaru N, Yoshimaru H, Kawahara T, Manabe T, Yamamoto S (2004). Patterns of pollen flow and genetic differentiation among pollen pools in Quercus salicina in a warm temperate old-growth evergreen broad-leaved forest. Silvae Genetica 53: 258-264. [online] URL: http://allgemeineforstundjagdzeitung.com/filead$\mathrm{min} /$ content/dokument/archiv/silvaegenetica/53 2004/53-5-6-258.pdf

Oddou-Muratorio S, Houot M-L, DemesureMusch B, Austerlitz F (2003). Pollen flow in the wildservice tree, Sorbus torminalis (L.) Crantz. I. Evaluating the paternity analysis procedure in continuous populations. Molecular Ecology 12: 3427-3439. - doi: 10.1046/j.1365-294X.2003. 01989.x

Oddou-Muratorio S, Klein EK, Austerlitz F (2005). Pollen flow in the wildservice tree, Sorbus torminalis (L.) Crantz. II. Pollen dispersal and heterogeneity in mating success inferred from parent-offspring analysis. Molecular Ecology 14: 4441-4452. - doi: 10.1111/j.1365-294X. 2005.02720.x

Pairon M, Jonard M, Jacquemart AL (2006). Modeling seed dispersal of black cherry, an invasive forest tree: how microsatellites may help? Canadian Journal of Forest Research 36: 13851394. - doi: 10.1139/x06-018

Pakkad G, Al Mazrooei S, Blakesley D, James C, Elliott S, Luoma-aho T, Koskela J (2008a). Genetic variation and gene flow among Prunus cerasoides D. Don populations in northern Thailand: analysis of a rehabilitated site and adjacent intact forest. New Forests 35: 33-43. - doi: 10.1007/s11056-007-9059-2

Pakkad G, Ueno S, Yoshimaru H (2008b). Gene flow pattern and mating system in a small population of Quercus semiserrata Roxb. (Fagaceae) Forest Ecology and Management 255: 38193826. - doi: 10.1016/j.foreco.2008.03.017

Pielaat A, Lewis M, Lele S, Decaminobeck T (2006). Sequential sampling designs for catching the tail of dispersal kernels. Ecological Modelling 190: 205-222. - doi: 10.1016/j.ecolmodel. 2005.02.023

Piotti A, Leonardi S, Buiteveld J, Geburek T, Gerber S, Kramer K, Vettori C, Vendramin GG (2012). Comparison of pollen gene flow among four European beech (Fagus sylvatica L.) populations characterized by different management regimes. Heredity 108: 322-331. - doi: 10.1038/ hdy.2011.77

Piotti A, Leonardi S, Piovani P, Scalfi M, Menozzi P (2009). Spruce colonization at treeline: where do those seeds come from? Heredity 103: 136-145. - doi: 10.1038/hdy. 2009.42

Pluess AR, Sork VL, Dolan B, Davis FW, Grivet D, Merg K, Papp J, Smouse PE (2009). Short distance pollen movement in a wind-pollinated tree, Quercus lobata (Fagaceae). Forest Ecology and Management 258: 735-744. - doi: 10.1016/ j.foreco.2009.05.014

Pollegioni P, Woeste K, Mugnozza GS, Malvolti ME (2009). Retrospective identification of hybridogenic walnut plants by SSR fingerprinting and parentage analysis. Molecular Breeding 24: 321-335. - doi: 10.1007/s11032-009-9294-7

Rathmacher G, Niggemann M, Köhnen M, Ziegenhagen B, Bialozyt R (2009). Short-distance gene flow in Populus nigra L. accounts for small-scale spatial genetic structures: implications for in situ conservation measures. Conservation Genetics 11: 1327-1338. - doi: 10.1007/ s10592-009-9961-6

Ribbens E, Silander JA, Pacala SW (1994). Seedling recruitment in forests: calibrating models to predict patterns of tree seedling dispersion. Ecology 75: 1794-1806. - doi: 10.2307/1939638

Ritland K (2002). Extensions of models for the estimation of mating systems using $\mathrm{n}$ indipendent loci. Heredity $88: 221-228$. - doi: $10.1038 /$ sj.hdy. 6800029

Robledo-Arnuncio JJ, Gil L (2005). Patterns of pollen dispersal in a small population of Pinus 
sylvestris L. revealed by total-exclusion paternity analysis. Heredity 94: 13-22. - doi: 10.1038/sj. hdy. 6800542

Robledo-Arnuncio JJ, Garcia C (2007). Estimation of the seed dispersal kernel from exact identification of source plants. Molecular Ecology 16: 5098-5109. - doi: 10.1111/j.1365-294X 2007.03427.x

Robledo-Arnuncio JJ, Austerlitz F, Smouse PE (2007). POLDISP: a software package for indirect estimation of contemporary pollen dispersal. Molecular Ecology Notes 7: 763-766. - doi: 10.1111/j.1471-8286.2007.01706.x

Robledo-Arnuncio JJ (2010). Wind pollination over mesoscale distances: an investigation with Scots pine. New Phytologist 190: 222-233. - doi: 10.1111/j.1469-8137.2010.03588.x

Salvini D, Bruschi P, Fineschi S, Grossoni P, Kjær ED, Vendramin GG (2009). Natural hybridisation between Quercus petraea (Matt.) Liebl. and Quercus pubescens Willd. within an Italian stand as revealed by microsatellite fingerprinting. Plant Biology 11: 758-765. - doi 10.1111/j.1438-8677.2008.00158.x

Savolainen O, Pyhajarvi T, Knurr T (2007). Gene flow and local adaptation in trees. Annual Review of Ecology, Evolution, and Systematics 38 595-619. - doi: 10.1146/annurev.ecolsys.38 091206.095646

Schnabel A, Hamrick JL (1995). Understanding the population genetic structure of Gleditsia triacanthos L.: the scale and pattern of pollen gene flow. Evolution 49: 921-931. - doi: 10.2307/ 2410414

Schuster WSF, Mitton JB (2000). Paternity and gene dispersal in limber pine (Pinus flexilis James). Heredity 84: 348-361. - doi: 10.1046/j. 1365-2540.2000.00684.X

Setsuko S, Ishida K, Ueno S, Tsumura Y, Tomaru $\mathrm{N}$ (2007). Population differentiation and gene flow within a metapopulation of a threatened tree, Magnolia stellata (Magnoliaceae). American Journal of Botany 94: 128-136. - doi 10.3732/ajb.94.1.128

Silva MB, Kanashiro M, Ciampi AY, Thompson I, Sebbenn AM (2008). Genetic effects of selective logging and pollen gene flow in a low-density population of the dioecious tropical tree $\mathrm{Ba}$ gassa guianensis in the Brazilian Amazon. Forest Ecology and Management 255: 15481558. - doi: 10.1016/j.foreco.2007.11.012

Silva CRS, Albuquerque PSB, Ervedosa FR, Mota JWS, Figueira A, Sebbenn AM (2011). Understanding the genetic diversity, spatial genetic structure and mating system at the hierarchical levels of fruits and individuals of a continuous Theobroma cacao population from the Brazilian
Amazon. Heredity 106: 973-985. - doi: 10.1038/ hdy.2010.145

Skarpaas O, Shea K, Bullock JM (2005). Optimizing dispersal study design by Monte Carlo simulation. Journal of Applied Ecology 42: 731739. - doi: 10.1111/j.1365-2664.2005.01056.x

Slavov GT, Howe GT, Adams WT (2005). Pollen contamination and mating patterns in a Douglasfir seed orchard as measured by simple sequence repeat markers. Canadian Journal of Forest Research 35: 1592-1603. - doi: 10.1139/x05-082

Slavov GT, Leonardi S, Burczyk J, Adams WT, Strauss SH, DiFazio SP (2009). Extensive pollen flow in two ecologically contrasting populations of Populus trichocarpa. Molecular Ecology 18: 357-373. - doi: 10.1111/j.1365-294X.2008. 04016.x

Stacy EA, Hamrick JL, Nason JD, Hubbell SP, Foster RB, Condit R (1996). Pollen dispersal in low-density populations of three Neotropical tree species. American Naturalist 148: 275-298. doi: $10.1086 / 285925$

Stoyan D, Wagner S (2001). Estimating the fruit dispersion of anemochorous forest trees. Ecological Modelling 145: 35-47. - doi: 10.1016/ S0304-3800(01)00385-4

Streiff R, Ducousso A, Lexer C, Steinkellner H, Gloessl J, Kremer A (1999). Pollen dispersal inferred from paternity analysis in a mixed oak stand of Quercus robur L. and Q. petraea (Matt.) Liebl. Molecular Ecology 8: 831-841. doi: 10.1046/j.1365-294X.1999.00637.x

Tabbener H (2003). The use of PCR based DNA markers to study the paternity of poplar seedlings. Forest Ecology and Management 179: 363-376. - doi: 10.1016/S0378-1127(02)00538-

Tani N, Tsumura Y, Kado T, Taguchi Y, Lee SL, Muhammad N, Ng KKS, Numata S, Nishimura S, Konuma A, Okuda T (2009). Paternity analysis-based inference of pollen dispersal patterns, male fecundity variation, and influence of flowering tree density and general flowering magnitude in two dipterocarp species. Annals of Botany 104: 1421-1434. - doi: 10.1093/aob/ mcp252

Vanden Broeck A, Cottrell J, Quataert P, Breyne P, Storme V, Boerjan W, Van Slycken J (2006). Paternity analysis of Populus nigra L. offspring in a Belgian plantation of native and exotic poplars. Annals of Forest Science 63: 783-790. - doi: 10.1051/forest:2006060

Wang KS (2004). Gene flow in European beech (Fagus sylvatica L.). Genetica 122: 105-113. doi: 10.1023/B:GENE.0000040999.07339.d4

Wang J, Ye Q, Kang M, Huang H (2008). Novel polymorphic microsatellite loci and patterns of pollen-mediated gene flow in an ex situ population of Eurycorymbus cavaleriei (Sapindaceae) as revealed by categorical paternity analysis. Conservation Genetics 9: 559-567. - doi: 10.1007/s10592-007-9369-0

Wang J, Kang M, Gao P, Huang H (2010a). Contemporary pollen flow and mating patterns of a subtropical canopy tree Eurycorymbus cavaleriei in a fragmented agricultural landscape. Forest Ecology and Management 260: 21802188. - doi: 10.1016/j.foreco.2010.09.016

Wang H, Sork VL, Wu J, Ge J (2010b). Effect of patch size and isolation on mating patterns and seed production in an urban population of Chinese pine (Pinus tabulaeformis Carr.). Forest Ecology and Management 260: 965-974. - doi: 10.1016/j.foreco.2010.06.014

White GM, Boshier DH, Powell W (2002). Increased pollen flow counteracts fragmentation in a tropical dry forest, an example from Swietenia humilis Zuccarini. Proceedings of the National Academy of Sciences 99: 2038-2042. - doi: 10.1073/pnas.042649999

Williams CG (2005). Framing the issues on transgenic forests. Nature Biotechnology 23: 530532. - doi: $10.1038 /$ nbt0505-530

Williams CG (2010). Long-distance pine pollen still germinates after meso-scale dispersal. American Journal of Botany 97: 846-855. - doi: 10.3732/ajb.0900255

Willson MF (1993). Dispersal mode, seed shadows, and colonization patterns. Vegetatio 107/108: 261-280. - doi: 10.1007/BF00052229

Xie C-Y, Knowles P (1994). Mating system and effective pollen immigration in a Norway spruce (Picea abies (L.) Karst) plantation. Silvae Genetica 43: 48-52.

Yehili J-L, N'Guetta Assanvo S-P, Gnagne M, Blanc G, Rodier-Goud M, Clément-Demange A, Sequin M, Fanjavola M (2007). Flux de gènes dans un verger à graines d'hévéas sauvages (Hevea brasiliensis Müll. Arg.). Cahiers Agricultures $16: 177-184$.

Zhang J-J, Ye Q-G, Yao X-H, Huang H-W (2010). Spontaneous interspecific hybridization and patterns of pollen dispersal in ex situ populations of a tree species (Sinojackia xylocarpa) that is extinct in the wild. Conservation Biology 24: 246-255. - doi: 10.1111/j.1523-1739.2009. 01357.x

\section{Supplementary Material}

Appendix 1 - List of 187 data points obtained from the 92 paternity analysis papers collected.

Link: Leonarduzzi_606@supp1001.pdf 